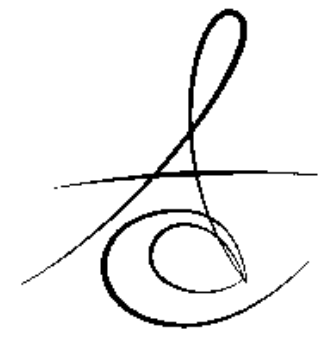

\title{
ÇOKLU İDİYOPATİK APİKAL KÖK REZORPSİYONU (OLGU SUNUMU)
}

\author{
MULTIPLE IDIOPATHIC APICAL ROOT RESORPTION (CASE REPORT)
}

\author{
Arş. Gör. Dt. Katibe Tuğçe TEMUR*
}

\author{
Arş. Gör. Dt. Ayfer ATAV ATEŞ ${ }^{* *}$
}

Makale Kodu/Article code: 3174

Makale Gönderilme tarihi: 05.12.2016

Kabul Tarihi: 21.02.2017

\section{öz}

Çoklu idiyopatik diş kökü rezorpsiyonu tek veya çok sayıda dişte görülebilen nadir karşılaşılan bir durumdur. Patolojik diş kökü rezorpsiyonu, lokal veya sistemik birçok faktöre bağlı olarak gelişebilir. Etyolojik herhangi bir neden tespit edilememesi halinde 'idiyopatik' tanımı kullanılır. Genellikle radyografide tesadüfen rastlanır. Ancak ciddi vakalarda ağrı ve mobiliteye neden olabilir. Bu çalışmada, etyolojinin belirlenemediği birden fazla dişi içeren eksternal apikal kök rezorpsiyonu olgusu sunulmaktadır. Bu olgu sunumunun amacı, nadir görülen çoklu idiyopatik apikal kök rezorpsiyonu vakalarında tedavi yaklaşımının değerlendirilmesidir.

Anahtar kelimeler: Çoklu Apikal Kök Rezorpsiyonu, İdiyopatik, Dental Radyografi, KIBT

\section{ABSTRACT}

Multiple idiopathic external root resorption is a rarely reported condition which has been observed in single or multiple teeth. Pathological tooth root resorption may develop due to many local or systemic factors. By definition, if no etiologic cause can be determined, the definition of 'idiopathic' is used. It is usually detected as an incidental radiographic finding. However, it may cause pain and mobility in severe cases. In this work, presents a case of external apical root resorption involving multiple teeth in which etiology was not identified. The aim of this case report is to evaluate the treatment approach in cases of rare multiple idiopathic apical root resorption.

Key words: Multiple Apical Root Resorption, Idiopathic, Dental Radiography, CBCT

\section{GİRIŞ}

İdiyopatik diş kökü rezorpsiyonu, tek veya çok sayıda dişi etkileyebilen nadir görülen bir durumdur. Patolojik diş kökü rezorpsiyonu, lokal veya sistemik bir çok faktöre bağı olarak gelişebilir. Ortodontik tedavi, travma, periapikal ya da periodontal inflamasyon, tümörler, kistler, oklüzal travma, gömülü sürnümerer dişler ve dişlerin reimplantasyonu patolojik kök rezorpsiyonuna yol açabilecek lokal faktörler arasındadır. ${ }^{1}$ Ortodontik kuvvetler, en sık karşılaşılan lokal nedendir. ${ }^{2}$ Hiperparatiroidizm, hipoparatiroidizm, hiperfosfatemi, hipofosfatemi, Gaucher hastalığı, Goltz sendromu, Papillon Lefevre sendromu, anakhoresis, Paget hastalığı, Turner sendromu ve beslenme alışkanlıkları ilgili endokrin bozukluklar ise sistemik faktörler arasında yer alır. Etyolojik herhangi bir neden tespit edilememesi halinde 'idiyopatik' tanımı kullanılır. İdiyopatik kök rezorpsiyonu genellikle radyografik muayenede tesadüfen tespit edilir. Başlangıçta asemptomatik olan dişlerde, ilerleyen zamanlarda mobilite artışı görülebilir. ${ }^{3,4}$ İdiyopatik kök rezorpsiyonu apikal ve servikal olmak üzere iki türdür. Servikal kök rezorpsiyonu, servikal bölgeden başlayıp pulpaya doğru ilerler. Daha az rastlanan tür olan apikal kök rezorpsiyonu ise apikal bölgeden başlayıp kuronale doğru kademeli olarak ilerler. ${ }^{5}$

\footnotetext{
* Çukurova Üniversitesi, Diş Hekimliği Fakültesi Ağız Diş ve Çene Radyolojisi AD, Adana.

${ }^{* *}$ Çukurova Üniversitesi, Diş Hekimliği Fakültesi Endodonti AD, Adana.

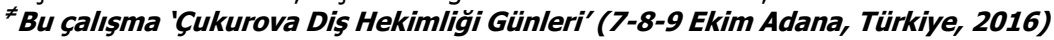

adlı sempozyumda poster bildirisi olarak sunulmuştur.
}

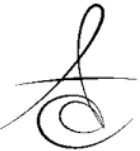


Bu çalışmada, nadir rastlanılan idiyopatik apikal diş kökü rezorpsiyonu rapor edilmiştir. Güncel literatür ışığında bu tür vakalarda, tedavi yaklaşımının değerlendirilmesi amaçlandı.

\section{OLGU}

17 yaşındaki kadın hasta diş çürükleri sebebi ile Ağız Diş ve Çene Radyolojisi kliniğine başvurdu. Hastadan alınan rutin panoramik radyografide diş çürüklerinin yanı sıra maksiler sağ ve sol, mandibular sağ ve sol premolar diş köklerinde çoklu rezorpsiyonlar görüldü (Resim-1). Hastadan alınan anamneze göre, bilinen bir sistemik hastalığının olmadığı, ortodontik tedavi görmediği, travma hikayesi olmadığı öğrenildi. Hastada, maksiller sol birinci molar dişte derin dentin çürüğü, maksiller sağ birinci premolar dişte derin dentin çürüğü ve apikal lezyon, maksiller sağ ikinci premolar dişte dentin çürüğü görüldü. Rezorpsiyon görülen diğer dişlerde diş çürüğü, periapikal, periodontal inflamasyon, diş kökü çevresinde herhangi bir tümör, kist, sürnümere diş görülmedi. Rezorpsiyonu fazla olan maksiller sağ ve sol, mandibular sağ ve sol ikinci premolar dişlerde mobilitenin arttığı görüldü. Uygulanan vitalite testi sonucu maksiller sağ birinci premolar diş hariç etkilenen diğer dişlerin vital olduğu görüldü. İlgili dişler ve çevre dokuları KIBT ile 3 boyutlu görüntülendi, rezorpsiyon varlığı doğrulandı (Resim-2, Resim-3, Resim-4, Resim-5). Hastadan alınan anamnez, yapılan klinik muayene ve radyografik bulgulara dayanarak çoklu idiyopatik apikal kök rezorpsiyonu tanısı konuldu. Hasta dental tedavilerin yapılması amacı ile ilgili bölümlere yönlendirildi ve tedavileri yapıldı (Resim-6). Periapikal lezyonu ve mobilitesi fazla olan maksiller sağ birinci premolar dişe uygulanan endodontik tedavi uygulanmasına rağmen, diş çekildi. Hastaya implant tedavisi önerildi. Rezorpsiyon görülen ancak herhangi bir semptom göstermeyen dişler için takip önerildi.

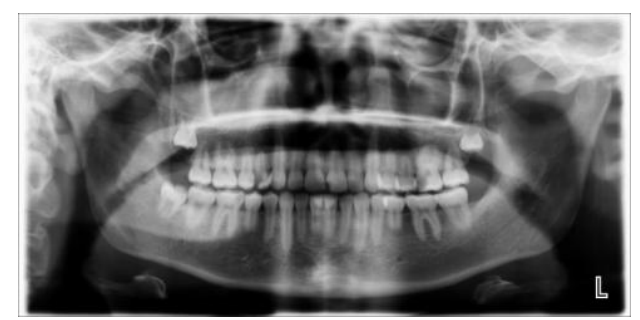

Resim 1. Hastanın ilk panoramik radyografi görüntüsü

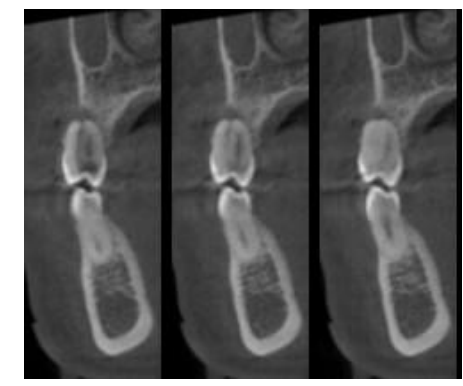

Resim 2. Rezorpsiyon görülen maksiller ve mandibular sağ birinci premolar dişlerin cross-sectional kesitte KIBT görüntüsü

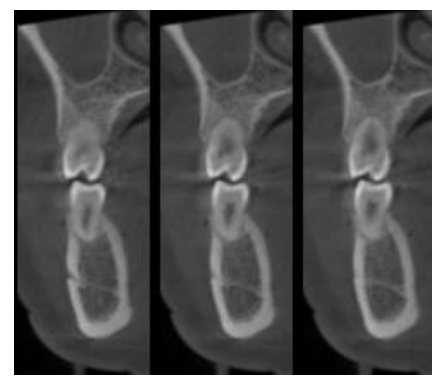

Resim 3. Rezorpsiyon görülen maksiller ve mandibular sağ ikinci premolar dişlerin cross-sectional kesitte KIBT görüntüsü

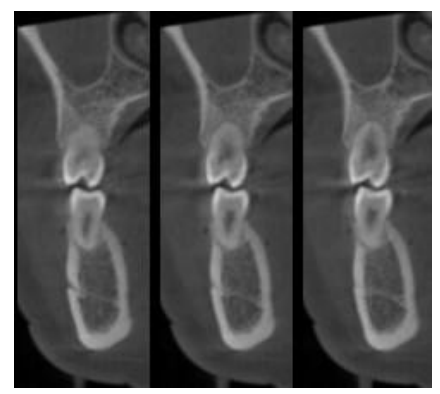

Resim 4. Rezorpsiyon görülen maksiller ve mandibular sol birinci premolar dişlerin cross-sectional kesitte KIBT görüntüsü

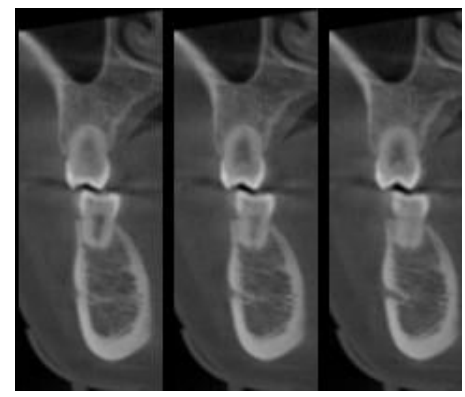

Resim 5. Rezorpsiyon görülen maksiller ve mandibular sol ikinci premolar dişlerin cross-sectional kesitte KIBT görüntüsü

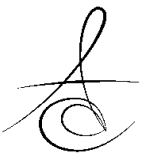




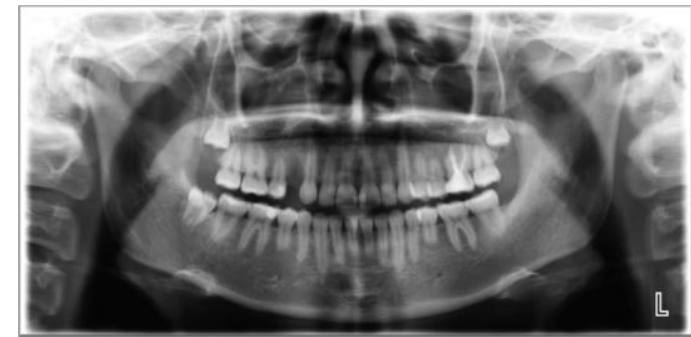

Resim 6. Hastanın tedavi sonrası panoramik radyografi görüntüsü

\section{TARTIŞMA}

Çoklu idiyopatik dış apikal kök rezorpsiyonu, dişhekimliğinde birden fazla dişi etkileyen nispeten nadir görülen bir durumdur. Hastalık asemptomatik olduğu için, genellikle rastlantısal radyografik bulgu olarak tespit edilir. Ancak ağır vakalarda ağrı ve hareketliliğe neden olabilir. Bu durum bazen kendi kendini sınırlar veya diş kaybına kadar ilerleyebilir. ${ }^{5}$

Literatürde çoklu idiyopatik diş kökü rezorpsiyonu az sayıda ve vaka raporu olarak bildirilmiştir 4,5,6,7,8. Bu vaka raporlarında, hastaların 14-39 yaş aralığında olduğu, olguların erkek cinsiyetinde (erkek/kadın,11/4) daha sık görüldüğü, sıklıkla premolar ve molar dişleri etkilediği bildirilmiştir.

İdiyopatik kök rezorpsiyonunun etyolojisi tam olarak bilinmemektedir. Saravia ve arkadaşları ${ }^{9}$ tek yumurta ikizi olan iki vaka bildirmiş ve idiyopatik kök rezorpsi- yonunun genetik ile ilişkili olabileceği ileri sürmüşlerdir. Diğer yandan, IL-1 genindeki polimorfizmlerin $^{10,11}$ veya IL-1 ile IL-IB geni polimorfizmlerin birlikteliğinin patolojik kök rezorpsiyonlarının gelişimi için yüksek bir risk olduğunu gösteren çalışmalar mevcuttur ${ }^{12}$. Bizim vakamızda, hastanın aile bireylerine ait panoramik röntgenleri incelendiğinde herhangi bir rezorpsiyon varlığına rastlanmamıştır ve ailede erken diş kaybı öyküsü olmadığı öğrenilmiştir. Soğur ve arkadaşları $^{13}$ tarafından bildiren vakada, rezorbe diş köklerini çevreleyen bölgede, osteoklastik aktiviteye tepki olarak kemikte aşırı üretim olduğu rapor edilmiştir. Bizim vakamıda histolojik herhangi bir inceleme yapılamamıştır. İdiyopatik kök rezorpsiyonun etyolojisini açıklayabilmek için daha çok vakada, histolojik ve mikroskobik çalışmalara ihtiyaç vardır.

Patolojik diş kökü rezorpsiyonlarının tedavisi etyolojik föktörü ortadan kaldırmaya yöneliktir. İdiyopatik kök rezorpsiyonunda ise etyoloji bilinmediği için, tedavi mevcut semptomlara ve kök rezorpsiyonun şiddetine bağlı olarak uygulanır. Etkilenen dişler asemptomatik ve vital ise, endodontik tedavi endike değildir. Vakaya periodontal tedavi eşçliğinde takip önerilir. ${ }^{5}$ Prognozu kötü olan dişlerin çekilmesi gerekebilir ve konvansiyonel sabit köprüler, hareketli parsiyel protezler veya implantlar kullanılarak restore edilebilir. Diğer yandan kök rezorpsiyonunun aktif olduğu alanlarda uzun dönem osseointegrasyon başarısı bilinmemektedir. ${ }^{4}$ Moazami ve arkadaşları ${ }^{3}$ tarafından bildirilen vakada alt anterior kesici dişlerin etkilenmediği rapor edilmiştir. Aynı çalışmada vaka, periodontal tedavi eşliğinde takip edilmiştir. Tüter ve arkdaşları $^{14}$ tarafından bildirilen vakada diş kökü rezorpsiyonu görülen dişlerin asemptomatik ve vital olması sebebi ile endodontik tedavi uygulanmamıştır. Hasta 3 aylık dönemlerle takip edilmiştir. Bizim vakamızda, prognozunun kötü olabileceği düşünülen maksiller sağ birinci premolar diş, endodontik tedavi uygulanmasına rağmen en nihayetinde çekilmiştir. Hastaya implant tedavisi önerilmiştir. Diğer rezorpsiyon görülen dişler için, hastaya 3 aylık dönemlerle takip önerilmiştir.

Literatürde bu tür olgularda ortodontik tedavi yaklaşımı farklılık göstermektedir. McMullin ve

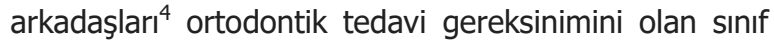
II, sınıf III maloklüzyonlu ve Down sendrom ile ilişkili sınıf III maloklüzyonlu üç vaka bildirmiştir. Aynı çalışmada, 2 vakada rezorpsiyonun fazla olması nedeni ile ortodontik kuvvetlerin durumun şiddetini artırabileceği düşünüldüğü için tedavi uygulanmamıştır. Bunun yanında, Down sendromu ile kısa diş kökü ve küçük kuron varlığı ile ilişkili olduğunu bildiren çalışmalar mevcuttur. ${ }^{15,16} \mathrm{Bu}$ açıdan bakıldığında Down sendromlu hastada görülen rezorpsiyonların 'idiyopatik' olarak adlandırması eleştirilebilir. Rey ve arkadaşları ise idiyopatik kök rezorpsiyonu olgusunda, etkilenen dişlere doğru- dan kuvvet uygulamadan, düşük kuvvetlerle ortodontik tedavi yapılabileceğini rapor etmişlerdir. ${ }^{17}$

\section{SONUÇ}

İdiyopatik apikal kök rezorpsiyonun etyolojisi belli değildir, yavaş veya hızlı ilerleyebilir ve dişlerin çoğunu etkileyebilir. Rezorpsiyon vakalarının bilinen konservatif tedavi yöntemi yoktur. Bu olgularda için periodontal tedavi eşliğinde takip önerilir, ilerleyen lezyonlarda diş çekimi yapılması gerekebilir. Ortodontik

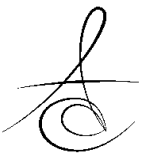


tedavi gereksinimini olan rezorpsiyonun şiddetli olmadığı olgularda, hafif kuvvetler ile ortodontik tedavi uygulanabilir.

Katibe Tuğçe Temur: ORCID ID: 0000-0001-9947-5679 Ayfer Atav Ateş: ORCID ID: 0000-0003-0270-8646

\section{KAYNAKLAR}

1. Schatzle M, Tanner SD, Bosshardt DD. Progressive, generalized, apical idiopathic root resorption and hypercementosis. J Periodontol 2005;76:2002-11.

2. Topkara A, Karaman AI, Kau CH. Apical root resorption caused by orthodontic forces: A brief review and a long-term observation. Eur J Dent 2012;6:445-53.

3. Moazami F, Karami B. Multiple idiopathic apical root resorption: a case report. Int Endod J 2007;40:573-8.

4. McMullin A, Fleming PS, Dibiase AT. Idiopathic generalized apical root resorption: a report of three cases. Int J Paediatr Dent 2008;18:312-6.

5. Bansal P, Nikhil V, Kapur S, Multiple idiopathic external apical root resorption: A rare case report, J Conserv Dent 2015;18:70-2.

6. Khojastepour L, Bronoosh P, Azar M. Multiple idiopathic apical root resorption: A Case report. J Dent (Tehran) 2010;7:165-9.

7. Kanungo M, Khandelwal V, Nayak UA, Nayak PA. Multiple idiopathic apical root resorption. BMJ Case Rep 2013:1-3.

8. Hegde S, Shubha AB, Kakti A, Rao BD. Extensive idiopathic external apical root resorption on a 13 year old child. J Clin Pediatr Dent 2012;36:28992.

9. Saravia ME, Meyer ML. Multiple idiopathic root resorption in monozygotic twins: Case report, Pediatr Dent 1989;11:76-8.

10. Al-Qawasmi RA, Hartsfield JK, Everett ET, Flury $L$, Liu L, Foroud TM, et al. Genetic predisposition to external apical root resorption in orthodontic patients: Linkage of chromosome-18 marker. J Dent Res 2003;82:356-60.

11. Urban D, Mincik J. Monozygotic twins with idiopathic internal root resorption: A case report. Aust Endod J 2010;36:79-82.
12. Iglesias-Linares $A$, Yañez-Vico $R$, BallestaMudarra S, Ortiz-Ariza E, Ortega-Rivera $H$, Mendoza-Mendoza A, et al. Postorthodontic external root resorption is associated with IL1 receptor antagonist gene variations. Oral Diseases 2012;18:198-205.

13. Sogur E, Sogur HD, Baksi Akdeniz BG, Sen BH. Idiopathic root resorption of the entire permanent dentition: systematic review and report of a case. Dent Traumatol 2008;24:490-5.

14. Tüter,G, Bal,B, Ayvaz,G, Baloş,K. İdiyopatik kök rezorpsiyonu (Bir olgu nedeni ile). Atatürk Üniv .Dişhek. Fak. Derg 1998;8:54-9.

15. Kelsen $A E$, Love RM, Kieser JA, Herbison P. Root canal anatomy of anterior and premolar teeth in Down's syndrome. Int Endod J 1999;32:211-6.

16. Desai SS, Down Syndrome: A Review of the Literature. Oral Surg Oral Med Oral Pathol Oral Radiol Endod 1997;84:279-85.

17. Rey D, Smit RM, Gamboa L, Orthodontic treatment in patient with idiopathic root resorption: a case report. Dental Press J Orthod 2015;20:108-17.

\section{Yazışma Adresi}

Katibe Tuğçe TEMUR

Çukurova Üniversitesi Dişhekimliği Fakültesi, Ağız Diş Ve Çene Radyolojisi Anabilim Dalı. Sarıçam, Adana, TÜRKİYE e-mail: tugce.uzmez@hotmail.com 